\section{Children with bronchial asthma assessed for psychosocial problems in a teaching hospital in Nigeria}

Mosunmola Florence Tunde-Ayinmode

University of Ilorin/ University of Ilorin Teaching Hospital, Department of Behavioural Sciences.

\section{Abstract:}

Background: Paediatric bronchial asthma causes respiratory related mortality and morbidity globally and elevates the risk of psychological and social problems (psychosocial problems); which may result in poorer asthma control. The rate of and associated factors for psychosocial problems among our asthmatic children was assessed in this study.

Methods: Seventy five (75) children aged 7 to 14 years with bronchial asthma who were attending clinics at the University of Ilorin Teaching Hospital, Ilorin, Nigeria, were assessed with Child behaviour questionnaire and a semi-structured questionnaire.

Results: Probable psychological morbidity was present in $25 \%$ of the children. The most frequently reported social impairResults: Probable psychological morbidity was present in $25 \%$ of the children. The most frequently reported social impait-
ments associated with the disease were: interference with play $(60 \%)$, domestic work $(49 \%)$, fear of dying anytime $(29 \%)$ ments associated with the disease were: interference with play $(60 \%)$, domestic work $(49 \%)$, fear of dying anytime $(29 \%)$
and feeling of being a burden on the family $(25 \%)$. Psychological morbidity was significantly associated with lower maternal education $(\mathrm{p}=0.020)$ and occupation $(\mathrm{p}=0.038)$, polygamy $(\mathrm{p}=0.012)$, fathers having more than 5 children $(\mathrm{p}=0.027)$ and mothers having inadequate spousal support $(\mathrm{p}=0.012)$. Inadequate spousal support and lower maternal occupational level were the significant predictors of morbidity following logistic regression.

Conclusion: Routine psychosocial assessment and care for children with asthma needs to be introduced into our clinics to help protect them and their families from avoidable suffering.

Keywords: Bronchial asthma, psychosocial problems, teaching hospital, Nigeria

DOI: http://dx.doi.org/10.4314/ahs.v15i2.49

\section{Introduction}

Bronchial asthma is a chronic respiratory disease that results from the effects of three main pathological processes namely airway obstruction, airway inflammation and bronchial hyper-responsiveness. ${ }^{1}$ It is a common disorder in childhood whose prevalence varies widely across the world; in Nigeria, the prevalence figure for bronchial asthma is considered to be $16.4 \% .{ }^{2}$ Bronchial asthma can be disabling and life threatening when severe, and generally has psychosocial impact because of its restrictions on and distuptions of emotional and social aspects of the patient's life. ${ }^{1,3}$ These psychological and social problems also referred to as psychosocial problems ${ }^{4}$ can be substantial if unmitigated. ${ }^{5,6}$ There are

\section{Corresponding author:}

Mosunmola Florence Tunde-Ayinmode

University of Ilorin/ University of Ilorin

Teaching Hospital, Department of

Behavioural Sciences.

Email: mosunmolaflorence@yahoo.com variations in the rate of psychological and social problems in paediatric asthmatic patients reported in literature. These variations depend on many factors like: the the study setting; measuring instruments used; the case definition standards used, the severity measures of the disease and the demographic factors of the group being studied.

A review of prevalence rate of psychopathology in several studies revealed a range from $16 \%$ to $52.3 \% 4,5,7,8$ and anxiety and depressive disorders as the commonest of anxiety problems known to co-occur with paediatric asthma are panic disorders, agoraphobia, generalised anxiety disorders, specific and social phobias, separation anxiety and many more. ${ }^{5,8}$ Social problems that may occur in asthma are also many, these include: educational problems, family dysfunction, stigma, parental distress, sibling resentment and jealousy, maternal over protectiveness and altered relationships with peers, it may also affect quality of life generally ${ }^{3,11-13}$ It is important to note that medications may contribute to the development of psychological problems in children with asthmethodology used; the geographical characteristic of mental disorders ${ }^{5,9,10}$ For example, the different kind ma. For example, Beta adrenergic agonists like salbutamol are known to be associated with anxiety symptoms whereas, prolonged use of steroids may predispose to depression..$^{10,14}$

Psychological problems are important in asthma care because they can precipitate attacks, make control difficult or even cause mortality. ${ }^{9,10}$ Depression is particularly recognized as carrying an elevated risk of more severe morbidity and mortality in asthma. ${ }^{10,14}$ Psychosocial problems constitute a barrier to self management of asthma and are also important because they can affect parent-child interactions and cause developmental, educational and behavioural problems in the child. ${ }^{11,1}$ The role of coping styles in psychosocial problems and asthma morbidity patterns have been explored. ${ }^{15} \mathrm{Cop}-$ ing styles like denial and avoidance are regarded as negative and inadequate because they are associated with poorer asthma control and worse morbidity patterns. ${ }^{1}$

To sum-up, the current trend in bronchial asthma management emphasizes modalities that prevent and control physical symptoms and manage accompanying psychosocial problems. This is why the research and development of strategies for tackling these psychosocial problems have received attention in many countries in recent times. Although this fact is equally recognized in Nigeria there are still very few studies on psychosocial problems of children with bronchial asthma in the country. In fact, despite rigorous literature search there are no published studies from the North-central region of Nigeria which is the setting of this study. In addition, there is evidence to show that many patients with asthma in Nigeria may not be getting adequate or up-to-date asthma care. ${ }^{16}$ Furthermore, paediatric psychosomatic medicine in Nigeria is still underdeveloped so is paediatric consultation-liaison psychiatry. ${ }^{17}$ Therefore, there is need for more interest and research in this area to establish the frequency of, and nature of these problems in order to develop and implement intervention measures.

This study is aimed at describing the psychosocial profile of a group of children attending clinics for management of bronchial asthma in order to understand the frequency of, and nature of these problems among them so that intervention program could be designed and implemented.

Westricted to children in the age group children less than 7 years are unlikely to comprehend and answer appropriately some of the questions on the psychological and social effects of the disease. Whereas, children older than 14years 
are less likely to be accompanied to the clinic by their Their study and this are similar in many respects first: CBQ was among the age group 7-14years. ${ }^{19}$ The study was conducted over a 6 month period. Ethi- Yoruba ethnic group was predominant, and lastly, islam cal approval for the study was sought and received from and christianity were the religions predominantly practhe ethical committee of the hospital.

Instruments: The child behaviour questionnaire (CBQ The semi-structured questionnaire was designed by the or Rutter Scale A2) ${ }^{20}$ and a semi-structured question- investigator and this had 5 sections namely: socio-denaire were used for the study. CBQ is an instrument mographic characteristics of the children and their that has been tested and used in many countries of mothers; physical functioning of the children; socia the world and has been found to be acceptable and functioning of the children and their mothers; family valid 19,21,22 $\mathrm{CBQ}$ has two versions, parents (Scale $\mathrm{A}$ ) and functioning and coping mechanisms uset by the chil teachers (Scale B). The teachers' version consists of 26- dren and their mothers. The responses to the question items and parents version 31-items, investigating the on social and family functioning were to be subjectively child's behaviour at school and at home respectively. rated by the children and mothers respectively as "not Both scales have undergone modification a few times at all", "a little", "moderately" or "severe".

and the latest forms are referred to as Scale A2 and The instruments were back-translated into Yoruba; the Scale B2. With Scale A2, parents are asked to indicate language spoken by majority of the people in the study the extent to which the statement applies to the child, setting so this version was used in participants that the frequency of occurrence of the behaviour or the were unable to speak or read English language. Both degree of its severity over a one year period. The parent the English and Yoruba versions of the questionnaires version was used in this study.

Each item on the scale is rated $0-2(0$; does not apply, 1; apply somewhat, 2; certainly apply). These produce a total score within the range of $0-62$. In the original wed to classify childen into cases (those ser ( this procedure being the first stage of the assessment process. In the second stage, cases were then subcategorized into neurotic, antisocial and mixed disorders based on subscales derived from specific items in the instrument. The neurotic subscale consists of items 3 13,19 and 28 and antisocial subscale consists of items 11, 16, 26, 30 and $31 .^{18}$ Those whose neurotic score exceed the antisocial are designated as "neurotic". And those with antisocial score exceeding the neurotic are designated "antisocial". The children with equal neurotic and antisocial scores are classified as having undesignated (mixed) disorder.

In the present study a cut-off of 7 as suggested by a EPI info 6.02 was used for the univariate analysis, simvalidation study by Omigbodun et $\mathrm{al}^{19}$ was used. In ple frequencies were generated, Chi-square test and their study the threshold of 7 on the scale, gave the best Fishers exact test were used to test for significant diftrade-off between a high sensitivity and a low false-pos- ferences. The preliminary results using the various deitive rate. At this threshold, sensitivity was 0.61 and grees of severity (mild, moderate and severe) yielded

specificity was 0.74 with a misclassification rate of 0.29 . invalid chi-square values (i.e. at least one expected value

were used in the study depending on which language participant felt more comfortable with. The instru-

ments were pre-tested using 5 patients each from the two clinics; the data of these patients were not included

Procedure: The investigator and two research assistants collected the data. Although the questionnaire was supposed to be self-administered it was read to the participants, as the pilot study showed some discrepancy ented literacy levels and competence in corectly filling the questionnaire. The children responded of the disease on them and the coping mechanism the use to reduce these effects while the mothers responded CBQ and also assisted in explaining to their children wey had difficulties responding adequately. A register was opened to keep records of participants interviewed to avoid double sampling.

\section{Data analysis}

was less than 5), hence, the merging of the effects (i.e. no effect, some effects) on social variables. P value less than 0.05 was set as the level for statistical sionificant difference. Data was exported to SPSS 15 for the purpose of carrying out multivariate analysis using logistic regression. Factors identified as significantly associated with psychological morbidity in the univariate analysis were entered as independent variables in multiple logistic regression stepwise backward elimination procedure to determine the most important predictors of morbidity. All the variables remained significant at the beginning of the process and were entered into the full model equation in logistic regression; no variable was deserving of removal on the basis of Multicollinearity. Variables were eliminated on the basis of Score statistics, Walds statistics and maximum likelihood ratio until no more could be removed; and the best fitting equation arrived at on the basis of the log odds associated with each variable calculated using logistic regression coefficients. The Hosmer and Lemeshow test of goodness of fit suggests that the full model was a good fit to the data as $\mathrm{p}=0.143(>0.05)$. $^{23}$
Results

There were 79 children with asthma accompanied by their mothers, 4 could not participate because their mothers had no interest or time to participate in the study.

Socio-demographic and family characteristics of the children

Male children (53\%) were slightly more than females $(47 \%)$. All the children were in school except one, of those in school $62 \%$ were in primary school. Virtually all $(95 \%)$ the children lived with at least one or both parents. Most of these parents had some form of formal education (mothers 68\% and fathers 84\%) and all were gainfully employed except for one father, but about half $(45 \%)$ of these mothers were engaged in unskilled jobs.

Most $(93 \%)$ mothers were currently married with $68 \%$ of them in monogamous relationships. Mothers with five or fewer number of children were the majority. Most of the children had mothers who reported adequate social support from their spouses. About $30 \%$ of the mothers could not effectively discuss asthma management with their affected children (Table 1).

However $40 \%$ of these mothers could not provide first aid asthma care ((Not on the table). 
Table 1: Socio-demographic and family characteristics of the children

\begin{tabular}{|c|c|c|c|}
\hline VARIABLES & & Frequency $(\mathrm{n})$ & Percentage (\%) \\
\hline \multirow[t]{2}{*}{ Age groups (years) } & $7-10$ & 40 & (53) \\
\hline & $11=14$ & 35 & (47) \\
\hline \multirow[t]{2}{*}{ Gender } & Male & 40 & (53) \\
\hline & Female & 35 & (47) \\
\hline \multirow[t]{3}{*}{ Child educational status } & None & 1 & (1) \\
\hline & Primary & 46 & (61) \\
\hline & Secondary & 28 & $(38)$ \\
\hline \multirow[t]{2}{*}{ Person with whom child resides } & One or Both Parents & 71 & (95) \\
\hline & Other Relatives & 4 & (5) \\
\hline \multirow[t]{2}{*}{ Mother's Age Group (years) } & Less or Equal 40 & 52 & (69) \\
\hline & Greater than 40 & 23 & (31) \\
\hline \multirow{4}{*}{ Mother's educational status } & None & 24 & (32) \\
\hline & Primary & 12 & (16) \\
\hline & Secondary & 30 & (40) \\
\hline & Tertiary & 9 & (12) \\
\hline \multirow{4}{*}{ Father's educational status } & None & 12 & (16) \\
\hline & Primary & 17 & (23) \\
\hline & Secondary & 21 & (28) \\
\hline & Tertiary & 25 & (33) \\
\hline \multirow{2}{*}{ Mother's Employment status } & Semi/Skilled Jobs & 41 & $(55)$ \\
\hline & Unskilled Jobs & 34 & (45) \\
\hline \multirow[t]{2}{*}{ Father's Employment status $(\mathrm{N}=71)$} & Semi/Skilled Jobs & 54 & (76) \\
\hline & Unskilled Jobs & 17 & (24) \\
\hline \multirow{2}{*}{ Mother's Marital status } & Currently married & 70 & (93) \\
\hline & Not currently married & 5 & (7) \\
\hline \multirow[t]{2}{*}{ Type of family } & Monogamy & 51 & (68) \\
\hline & Polygamy & 24 & (32) \\
\hline \multirow[t]{2}{*}{ Number of Mother's Children } & Less or Equal 5 & 53 & (71) \\
\hline & Greater than 5 & 22 & (29) \\
\hline \multirow[t]{3}{*}{ Spousal support for child care } & Adequate & 64 & (89) \\
\hline & Inadequate & 5 & (7) \\
\hline & Don’t know & 3 & (4) \\
\hline Mother discuss asthma & Yes & 22 & (29) \\
\hline management effectively well & No & 53 & (71) \\
\hline \multirow[t]{2}{*}{ Number of Father's Children } & Less or Equal 5 & 42 & (56) \\
\hline & Greater than 5 & 33 & (44) \\
\hline
\end{tabular}

Clinical variables examined in relation to severity $3(4 \%)$ twice or more. In terms of school days missed of asthma because of asthma $58(78 \%)$ had not missed school in Three severity indicators were analysed namely self-re- the preceding 3 terms (one school year), $9(12 \%)$ had port of frequency of hospital visits to any health facil- missed school once and $7(10 \%)$ had missed school 2 or ity including ours, hospital admissions ever and school more times.

days missed per term because of asthma (a school term

in Nigeria varies but it is roughly 80 days); 48(64\%) chil- Social effects of bronchial Asthma on the children dren had not visited any health facility in the 3 months In terms of the social effects of asthma many of the preceding study; $13(17 \%)$ had visited once and $14(19 \%) \quad$ children did not report impairment in their social lives. had visited 2 or more times (all who visited reported The 4 most frequent areas in which the disease affected it was for minor ailments and not for asthma attacks); these children most were: interference with play $(60 \%)$ $61(81 \%)$ had never been admitted because of bronchi- interference with domestic work (49\%), fear of dying al asthma while $11(15 \%)$ had been admitted once and anytime $(29 \%)$ and $25 \%$ felt they were a burden on their families (Table 2).
Table 2: Socio-psychological effects of Asthma on affected children

\begin{tabular}{lllll}
\multicolumn{1}{c}{ VARIABLES } & \multicolumn{2}{l}{$\begin{array}{l}\text { No effect } \\
\text { Freq. (\%) }\end{array}$} & \multicolumn{2}{l}{$\begin{array}{l}\text { Some effects } \\
\text { Freq. (\%) }\end{array}$} \\
\hline Interference with play activities & 30 & $(40)$ & 45 & $(60)$ \\
Interference with domestic work & 38 & $(51)$ & 37 & $(49)$ \\
I am afraid I may die anytime & 53 & $(71)$ & 22 & $(29)$ \\
I feel a burden to my family & 56 & $(75)$ & 19 & $(25)$ \\
I feel my classmates see me as different & 61 & $(81)$ & 14 & $(19)$ \\
I feel people discriminate against me & 62 & $(83)$ & 13 & $(17)$ \\
I feel that people bother me a lot & 65 & $(87)$ & 10 & $(13)$ \\
I feel inferior to other children & 66 & $(88)$ & 9 & $(12)$ \\
I feel I may not achieve much in life & 71 & $(95)$ & 4 & $(5)$ \\
I feel I have given my family a bad image & 71 & $(95)$ & 4 & $(5)$ \\
I feel I have bad luck & 72 & $(96)$ & 3 & $(4)$ \\
I find it difficult making friends & 73 & $(97)$ & 2 & $(3)$ \\
\hline
\end{tabular}

\section{CBQ score of the children}

dorsed items on CBQ in order of frequency. The highThere were only $19(25 \%)$ children classified as est score on CBQ was recorded in the item on asthma high-scorers or cases of probable psychological mor- or attacks of wheezing $(100 \%)$ apart from this; the next bidity on CBQ. Those who scored below 7 were classi- 7 most frequent positive items were: 'Headaches' $(60 \%)$; fied as low-scorers or non-cases.

Often disobedient (27\%); 'Stomach ache or vomiting' Table 3: Shows the frequency of the more positively en- (24\%) 'Wets bed or pants' $(20 \%)$; Very restless $(20 \%)$; 'Temper tantrums' (17\%) and 'Often lies' (17\%), (Table

Table 3: The More Frequently Positively Endorsed Items on CBQ

\begin{tabular}{lll}
\multicolumn{1}{c}{ VARIABLES } & $\begin{array}{c}\text { Frequency } \\
\mathbf{N}=\mathbf{7 5})\end{array}$ & $\begin{array}{l}\text { Percentage } \\
(\%)\end{array}$ \\
\hline Asthma or attack of wheezing & 75 & $(100)$ \\
Headaches & 45 & $(60)$ \\
Often disobedient & 20 & $(27)$ \\
Stomach ache or Vomiting & 18 & $(24)$ \\
Wet bed or pant & 15 & $(20)$ \\
Very restless & 15 & $(20)$ \\
Temper tantrums & 13 & $(17)$ \\
Often tell lies & 13 & $(17)$ \\
Frequently fight other children & 12 & $(16)$ \\
Irritable & 11 & $(15)$ \\
Bullies other children & 11 & $(15)$ \\
Often destroy own or others property & 10 & $(13)$ \\
Bites nails or fingers & 8 & $(11)$ \\
\hline
\end{tabular}


Univariate analysis of associated factors of psychological morbidity: morbidity on the basis of CBQ score was significantly 16.22), unskilled jobs ( $\mathrm{OR}=3.61 \mathrm{CI}=1.06-12.74)$, poassociated with a child having a mother with the follow- lygamous relationships $(\mathrm{OR}=4.55 \mathrm{CI}=1.33-15.94)$ and ing: less than secondary school education $(\mathrm{X} 2=5.42 ; \mathrm{p}<\quad$ those whose father had more than 5 children $(\mathrm{OR}=3.90$ $0.020)$, being engaged in unskilled jobs $(\mathrm{X} 2=4.30 ; \mathrm{p}<\mathrm{CI}=1.14-13.81)$. The odds was 16 times higher in chil$0.038)$, being in polygamous relationships ( $\mathrm{X} 2=6.33$; dren whose mothers were not adequately supported by $\mathrm{p}<0.012)$ and having inadequate support from spouse their husbands when compared with those with good for the care of the child with asthma $(\mathrm{X} 2=5.97 ; \mathrm{p}<$ support (OR=15.69 CI=1.42-403.09) (Table 4).

0.012). It was also associated with having a father with

Table 4: Socio-demographic and Clinical correlates of probable cases and Non-Cases of

psychological morbidity identified by CBQ (Rutter Scale A2)

\begin{tabular}{|c|c|c|c|c|c|c|}
\hline \multicolumn{2}{|l|}{ VARIABLES } & $\begin{array}{l}\text { Cases } \\
\mathrm{N}_{1}=19\end{array}$ & $\begin{array}{l}\text { Non-Cases } \\
\mathrm{N}_{2}=56\end{array}$ & Odd Ratio & $\begin{array}{l}\text { Confidence } \\
\text { Interval } \\
\text { (CI) }\end{array}$ & $P$ value \\
\hline Gender & $\begin{array}{l}\text { Male } \\
\text { Female }\end{array}$ & $\begin{array}{l}11 \\
8\end{array}$ & $\begin{array}{l}29 \\
27\end{array}$ & 1.28 & $0.04-4.76$ & 0.845 \\
\hline Age Group & $\begin{array}{l}\leq 10 \text { years } \\
>1 \text { yyears }\end{array}$ & $\begin{array}{l}11 \\
8\end{array}$ & $\begin{array}{l}29 \\
27\end{array}$ & 1.28 & $0.04-4.76$ & 0.845 \\
\hline Child Education & $\begin{array}{r}\text { Primary } \\
\text { Secondary }\end{array}$ & $\begin{array}{l}14 \\
5\end{array}$ & $\begin{array}{l}32 \\
23\end{array}$ & 2.01 & $0.56-7.51$ & 0.354 \\
\hline $\begin{array}{l}\text { Average school days } \\
\text { missed per term }\end{array}$ & $\begin{array}{l}0-1 \\
\geq 2\end{array}$ & $3^{16}$ & $\begin{array}{l}51 \\
4\end{array}$ & 0.42 & $0.07-2.68$ & 0.363 \\
\hline $\begin{array}{l}\text { No. of Hospital visits } \\
\text { in } 6 \text { months }\end{array}$ & $\begin{array}{l}0-1 \\
\geq 2\end{array}$ & $\begin{array}{l}16 \\
3\end{array}$ & $\begin{array}{l}45 \\
11\end{array}$ & 1.30 & $0.28-6.78$ & 1.000 \\
\hline $\begin{array}{l}\text { Previous Hospital } \\
\text { Admissions }\end{array}$ & $\begin{array}{l}\text { None } \\
\geq 1\end{array}$ & $\begin{array}{l}15 \\
4\end{array}$ & $\begin{array}{l}46 \\
10\end{array}$ & 0.82 & $0.19-3.46$ & 0.743 \\
\hline $\begin{array}{l}\text { Mothers age } \\
\text { groups (years) }\end{array}$ & $\begin{array}{l}\leq 40 \\
>40\end{array}$ & $\begin{array}{l}10 \\
9\end{array}$ & $\begin{array}{l}42 \\
14\end{array}$ & 0.37 & $0.11-1.25$ & 0.124 \\
\hline $\begin{array}{l}\text { Mothers } \\
\text { Education }\end{array}$ & $\begin{aligned} & \leq \text { Primary } \\
\geq & \text { Secondary }\end{aligned}$ & $\begin{array}{l}14 \\
5\end{array}$ & $\begin{array}{l}22 \\
34\end{array}$ & 4.33 & $1.22-16.22$ & 0.020 \\
\hline $\begin{array}{l}\text { Fathers } \\
\text { Education }\end{array}$ & $\begin{array}{r}\quad \leq \text { Primary } \\
\geq \text { Secondary }\end{array}$ & $\begin{array}{l}11 \\
8\end{array}$ & $\begin{array}{l}18 \\
38\end{array}$ & 2.90 & $0.88-9.71$ & 0.086 \\
\hline Mother's Job & $\begin{array}{r}\text { Unskilled } \\
\text { Semi/Skilled }\end{array}$ & $\begin{array}{l}13 \\
6\end{array}$ & $\begin{array}{l}21 \\
35\end{array}$ & 3.61 & $1.06-12.74$ & 0.038 \\
\hline Father's Job & $\begin{array}{l}\text { Unskilled } \\
\text { Semi/Skilled }\end{array}$ & $\begin{array}{l}7 \\
11\end{array}$ & $\begin{array}{l}11 \\
42\end{array}$ & 2.43 & $0.66-8.99$ & 0.225 \\
\hline Type of Family & $\begin{array}{r}\text { Polygamy } \\
\text { Monogamy }\end{array}$ & $\begin{array}{l}11 \\
8\end{array}$ & $\begin{array}{l}13 \\
43\end{array}$ & 4.55 & $1.33-15.94$ & 0.012 \\
\hline $\begin{array}{l}\text { Mothers No. } \\
\text { of Children }\end{array}$ & $\begin{array}{l}\geq 6 \\
\leq 5\end{array}$ & $\begin{array}{l}9 \\
10\end{array}$ & $\begin{array}{l}13 \\
43\end{array}$ & 2.98 & $0.88-10.25$ & 0.088 \\
\hline $\begin{array}{l}\text { Fathers No. } \\
\text { of Children }\end{array}$ & $\begin{array}{l}\geq 6 \\
\leq 5\end{array}$ & $\begin{array}{l}13 \\
6\end{array}$ & $\begin{array}{l}20 \\
36\end{array}$ & 3.90 & $1.14-13.81$ & 0.027 \\
\hline $\begin{array}{l}\text { Husband } \\
\text { Support }\end{array}$ & $\begin{array}{r}\text { Inadequate } \\
\text { Adequate } \\
\end{array}$ & $\begin{array}{l}4 \\
13 \\
\end{array}$ & $\begin{array}{l}1 \\
51 \\
\end{array}$ & 15.69 & $1.42-403.09$ & 0.012 \\
\hline
\end{tabular}

Multivariate analysis of factors associated with child psychological morbidity:

At the end of all possible steps and iterations children with mothers who had less than secondary education $(\operatorname{Exp~B}=0.175 ; \mathrm{p}=0.016 ; \mathrm{CI}=0.042-0.721)$ and those who were not adequately supported by their spouses remained $(\operatorname{Exp~B}=21.085 ; \mathrm{p}=0.027$; $\mathrm{CI}=1.408-315.826)$ significantly associated with psychological morbidity.

\section{Coping with asthma}

When the children were asked on how and what helped them cope with their asthma the divergent responses were categorised under the following: praying, seeking help from medical providers (medical based), seeking help from family and friends (social based) and trying to avoid thinking or talking about the problem (psychological based). The most frequently reported method used was prayers; used in isolation by $22(29 \%)$ children, followed by medical methods alone by $20(27 \%)$, then avoidance $18(24 \%)$ and then social $6(9 \%)$. There were $9(12 \%)$ children who reported using combination of prayers and medical method of coping (Not on table).

\section{Discussion}

In this study the psychological and social problems of children with bronchial asthma was assessed for detection and perceptive purposes. The idea was informed by the fact that our asthmatic children did not hitherto receive any formal psychosocial assessment or care for their condition at the clinic level contrary to increasing global trend which integrate medical therapy with psychosocial care, which is known to be superior to those that ignore the latter. ${ }^{24,25}$ Gathering and using psychosocial data is therefore of great importance in asthma care. The psychosocial problems of children with bronchial asthma in our clinical setting were explored. The rate of psychological morbidity among our paediatric asthma patients was based on CBQ scores.

Factors found to be associated with psychological motbidity were low maternal education, mothers having unskilled jobs, polygamy, large family size and poor spousal support for the care of the child. However, mothers having low education and inadequate support from their spouses were predictors of psychological morbidity in these children. Interference with domestic work and play activities were the most frequently reported social impairments by these children. It is important to note that majority of the asthmatic children in this study had morbid
When the rate of psychological morbidity in this study is compared with some previous studies ${ }^{4,8,9,26}$, it was considered relatively lower. While it is recognised that rates of psychopathology in chronic diseases like asthma may vary widely because of various factors like methodology and geographical location of study. The difference may lie in the lesser degree of severity of asthma in these children when compared with studies reviewed. Also, these other studies used diagnostic instruments while this study used only a screening instrument that could only give probable psychological morbidity. Furthermore, children in this study were a highly select group attending a tertiary health institution, majority of who were probably in the middle socio-economic status, which may have lowered the probability of being maladjusted compared to the community sample in some of the reviewed studies. $4,8,9,26$

Factor analysis of symptom profile in CBQ in this study revealed the most frequently reported items for which $20 \%$ or more of the children were positive as: "headaches" "stomach aches or vomiting" "often disobedient" "wets bed or pants" and "very restless". These symptoms may suggest more of anxiety disorder. Although diagnostic categorization was not done in this study nevertheless this may support some studies which dentify anxiety disorders as very common among children with bronchial asthma., ${ }^{5,7}$ some studies however, report depressive disorders as also very common or even having higher prevalence among these patients while co-morbidity of anxiety and depression are also known to commonly occur too. ${ }^{9,10}$ Whatever the disorder that is identified the important point is that physicians caring for children with bronchial asthma should be on the lookout for any evidence of psychological dysfunction, which should be detected and managed early so that adverse effects can be prevented.

Various social problems were identified among our paediatric asthma patients that required intervention. Some of these were analysed to determine whether they influenced the rate of psychological morbidity of the children. Lower maternal socio-economic status in this study (as marked by lower educational and occupationmorbid was associated with increased psychologica 
of the two significant predictors of child psychological morbidity in the logistic regression analysis, indicating its value in assessing or monitoring risk of psychological morbidity in this study. Children from lower socioeconomic background are known to have poorer symptoms control and outcomes. ${ }^{1,27}$ Low socio-economic status of mothers may translate to social impairment or deficiency in many areas such as finance, self and home management, knowledge about the disease, and ability to understand asthma education. ${ }^{1,27}$ Low socio-economic status may also be related to poor environment which may harbour many of the environmental precipitants of asthma such as house dust mites, pollens, moulds; cockroaches, dust, and smoke.

There was also evidence that some of the children had different degree of difficulties in their family lives, in a number of them, it negatively impacted on their psychological status. Large family size from paternal perspective, poor or inadequate spousal support for the care of the child with asthma and polygamy were family formation, relational and structural factors that were associated with psychological morbidity in our paediatric asthma clinics.

Family factors have always received attention in literature as being able to influence onset and course of asthma and as risk factor of psychological morbidity in both child and family members. ${ }^{1,24}$ Family structure, function and dynamics affect the interactions of parent-child interaction which in turn affects the management and manageability of the disease. If parent-child interactions are dysfunctional then the risk of poor outcome is elevated.

Polygamy as found in this study is a recognized risk factor for psychological morbidity in children ${ }^{28,29}$, often polygamous families are larger and resource allocation per member is likely to be smaller. The chances that an affected child will not get enough resources for his/he care in a large family is high and may carry with it an elevated risk of poor asthma control and psychological morbidity.

The significant association of inadequate spousal support and psychological morbidity of asthmatic children in this study support some previous studies which suggest that family dysfunction elevates the risk of psychological impairment in affected children. ${ }^{11,30}$ Specifically, inadequate spousal support in terms of finance, time and emotion may be manifestation of a dysfunction- al family system. ${ }^{11}$ Caring for an ill child could lead to neglect of parents having disharmonious relationships as well. This cycle of events may affect the care of the child with asthma and elevate the risk of psychological impairment. ${ }^{11,30}$

Although, most of the mothers in this study were young and fairly educated a substantial number of them could not effectively discuss asthma management with their affected children neither could they confidently offe first aid care at home. Poor knowledge was identified by a previous study as a factor that affects self-care. ${ }^{31}$ Asthma self-care is a very important component of effective management of the disease. Self care requires that parents should be able to discuss the various aspects of the disease with the affected children and offer effective preventive care and first aid at home. The knowledge gap identified by this study needs to be filled through improved asthma education programs at the clinic and community levels.

The reason why children or families of children with physical illness experience psychological dysfunction while others do not has to do with coping among other things. All things or ways used to mitigate stress can simply be regarded as coping method. In this study, praver was the most frequently reported coping method used by the children and this is consistent with the finding in a previous study among children with sickle cell disease $e^{32}$; the high level of religiosity in our setting may have contributed to this finding. Prayers as coping method have been studied in many chronic diseases ${ }^{33,34}$ and its effectiveness as coping method is recognized, albeit debated by many, but confirmed by some. $.^{34} \mathrm{Neg}-$ ative coping method like avoidance or denial ${ }^{15,35}$ was used by about a quarter of the children in this study this would need modification through family psycho-education.

More than half of the children in this study reported mpairment in their domestic and play activities which may be related to the symptom of the disease or to it management. The implication of this finding is the necessity to put in place psychosocial care to help educate the patients and their families on preventive measures; for instance where work precipitate attacks, precautionary medication(s) can be taken before such work is started. Also where medications precipitate or make worse an attack, a lower dose can be used or alternatives provided.

\section{Limitations}

This study has its limitations which include the non use of diagnostic instrument which precluded the identification of definite psychopathologies. Its cross sectional nature and non randomized sampling technique also precluded the assignment of cause and effect relationships to the associated factors identified. While its hospital based nature limits it generalization to the wider community of children with bronchial asthma. However, the study has provided evidence that there are problems and could form the basis for future and larger studies that would take care of these limitations.

\section{Conclusion}

In this study a quarter of children attending our clinics for asthma care may be psychologically impaired and factors associated with this include low maternal socio-economic status, polygamy and poor spousal support. In addition, the disease interfered with the play and domestic activities of large number of the asthmatic children. These children need psychosocial intervention. Factors associated with psychological morbidity need to be modified or ameliorated. On the whole the study suggests that emotional and behavioural component of asthma care should be accorded priority in our paediatric clinics so that psychopathologies can be discover early and treated appropriately or prevented entirely.

\section{Conflict of interest:}

Author declares no conflict of interest

\section{References}

1. Bacon SL, Bouchard A, Loucks EB, Lavoie KL. Individual-level socioeconomic status is associated with worse asthma morbidity in patients with asthma. Respiratory Research 2009, 10:125. doi:10.1186/1465-9921$10-125$

2. Falade AG, Olawuyi F, Osinusi K, Onadeko BO, Prevalence and severity of symptoms of asthma, allergic rhino-conjunctivitis and atopic eczema in secondary school children in Ibadan, Nigeria. East Afr Med J. 1998 75(12):695-8.

3. Tseng TJ, Chou CC. Parental stress in mothers of children with asthma. Hu Li Za Zhi. 2006; 53(4):31-40. 4. Weil CM, Wade S, Holden G, Mitchell H, Evans R,
Kruszon-Moran D, et al. Psychosocial characteristics of inner-city children with asthma: a description of the NCICAS psychosocial protocol. National Cooperative Inner-City Asthma Study. Pediatr Pulmonol. 1997; 24(4):263-76.

5. Goodwin RD, Messineo K, Bregante A, Hoven CW, Kairam R. Prevalence of probable mental disorders among pediatric asthma patients in an inner-city clinic. Asthma. 2005; 42(8):643-647.

6. Rhee H, Belyea MJ, Ciurzynski S, Brasch J, A Self-Management in Adolescents: Relationships to Psychosocial Factors. Pediatr Pulmonol. 2009; 44(2): 183-191. doi: 10.1002/ppul.20972/

7. Vila G, Nollet-Clemençon C, de Blic J, Mouren-Simeoni MC, Scheinmann P. Prevalence of DSM IV anxiety and affective disorders in a paediatric population of asthmatic children and adolescents. I Affect Disord. 2000; 58(3):223-31.

8. Katon W, Lozano P, Russo J, McCauley E, Richardson L, Bush T. The Prevalence of DSM-IV Anxiety and Depressive Disorders in Youth with Asthma Compared to Controls. J Adolesc Health. 2007; 41(5): 455-463. doi: 10.1016/j.jadohealth.2007.05.023

Kotrotsiou E, Krommydas G, Papathanasiou I, Kotrotsiou S, Paralikas T, Lahana E, et al. Anxiety and depression in teenagers and young adults with Asthma. Health Science Journal 2011; 5(3):229-236.

10. Kaugars AS, Klinnert MD, Bender BG. Family Influences on Paediatric Asthma J Paediatr. Psychol. 2004; 29(7): 475-491. doi: 10.1093/jpepsy/jsh051

1.Özkaya E, Çetin M, Uğurad Z, Samancı N. Evaluation of family functioning and anxiety- depression parameters in mothers of children with asthma. Allergol Immunopathol (Madr). 2010; 38:25-30.

12. Nagano J, Kakuta C, Motomura C, Odajima H, Sudo N, Nishima S, et al. The parenting attitudes and the stress of mothers predict the asthmatic severity of their children: a prospective study. BioPsychoSocial Medicine. 2010; 4:12. doi:10.1186/1751-0759-4-12

3. Murdock KK, Robinson EM, Adams SK, Berz J Rollock MJ. Family-school connections and internalzing problems among children living with asthma in urban, low-income neighbourhoods. J Child Health Care. 2009; 13(3):275-94.

14. Opolski M, Wilson I. Asthma and depression: pragmatic review of the literature and recommendations for future research. Clinical Practice and Epidemiology in Mental Health 2005; 1:18. doi:10.1186/1745-0179-1- 
15. Barton C, Clarke D, Sulaiman N, Abramson M. Coping as a mediator of psychosocial impediments to optimal management and control of asthma. Respir Med. 2003; 97(7):747-61.

16. Ayuk A, Iloh K, Obumneme-Anyim I, Ilechukwu G, Oguonu T. Practice of asthma management among doctors in south-east Nigeria. Afri J Resp Med. 2010: 14-17.

17. Bakare MO, Omigbodun OO, Kuteyi OB, Meremikwu MM, Agomoh AO. Psychological complications of childhood chronic physical illness in Nigerian children and their mothers: the implication for developing paediatric liaison services. Child Adolesc Psychiatry Ment Health. 2008; 19:2(1)34.

18. Tunde-Ayinmode MF, Adelekan ML. Psychosocial impact of sickle cell disease in children seen at Universit of Ilorin Teaching Hospital, Ilorin, Nigeria. East Africa Medical Journal 2005; 82(2):73-78.

19. Omigbodun O, Gureje O, Gater R, Ikuesan B, Adebayo E. Psychiatric morbidity in a Nigerian paediatric primary care service: a comparison of two screening instruments. Soc Psychiat Psychiatric Epid, 1996, 34:186-193. 20. Rutter M, Tifard J, Whitemore KL. Education Health Behaviour. London, Longmans, 1970.

21 Boyle MH, Jones SC. Selecting measures of emotional and behavioural disorders of childhood for use in general populations. J Child Psychol Psychiatry. 1985; 26 (1): 137-159.

22. Deans AG, Deans JA, Burton AH, Dicker RC. Epi-Info version 6: A word processing data base and statistical system for epidemiology on micro computers USD incorporated, Stone Mountain, GA: 1994.

23. Statistical Package for Social Sciences (SPSS) (2006) Version 16. SPSS Inc., Chicago Ill.

24. Harrison BDW. Psychosocial aspects of asthma in adults. Thorax. 1998; 53:519-525. doi:10.1136/ thx.53.6.519

25. Sadof M, Kaslovsky R. Adolescent asthma: a developmental approach. Current Opinion in Paediatrics. 2011; 23:373 - 378.

26. Feldman JM, Ortega AN, McQuaid EL, Canino G.
Comorbidity Between Asthma Attacks and Internalizing Disorders Among Puerto Rican Children at OneYear Follow-Up. Psychosomatics. 2006; 47(4): 333-339. doi: 10.1176/appi.psy.47.4.333.

27. Feldman JM, Siddique MI, Morales E, Kaminski B, Shou-En LU, Lehrer PM. Psychiatric Disorders and Asthma Outcomes Among High-Risk Inner-City Patients. Psychosomatic Medicine. 2005; 67:989-996. 989 0033-3174/05/6706-0989

28. Al-Krenawi A, Graham JR, Al Gharaibeh F. A Comparison Study of Psychological, Family Function Marital and Life Satisfactions of Polygamous and Monogamous Women in Jordan. Community Mental Health Journal. 2011; 47(5) 594-602. doi: 10.1007/s10597-0119405-x

29. Al-Krenawi A, Slonim-Nevo V. Psychosocial and Familial Functioning of Children From Polygamous and Monogamous Families. International J Social Psychiatry. 2006; 52(1):5-17.

30. Wamboldt MZ, Wamboldt FS. Role of the family in the onset and outcome of childhood disorders: selected research findings. J Am Acad Child Adolesc Psychiatry. 2000; 39(10):1212-9.

31. Vamos M, Kolbe J. Psychological Factors in Severe Chronic Asthma. Aust N Z J Psychiatry 1999; 33(4):538544. doi: 10.1080/j.1440-1614.1999.00591.x .

32. Cotton S, Grossoehme D, McGrady ME. Religious coping and the use of prayer in children with sickle cell disease. Paediatr Blood Cancer. 2012; 58(2):244-9. doi: 10.1002/pbc.23038. Epub 2011 Feb 11.

33. Rew L, Wong JY, Weylin sternglanz R . The relationship between prayer, health behaviours, and protective resources in school-age children. Issues in Comprehensive Paediatric Nursing. 2004; 27(4):245-255.

34. Wong YJ, Rew L, Slaikeu KD. A systematic review of recent research on adolescent religiosity/spirituality and mental health. Issues in Mental Health Nursing. 2006; 27(2): 161-183.

35. González-Freire B, Vázquez-Rodríguez I, Marcos-Velázquez P, de la Cuesta CG. Repression

and coping styles in asthmatic patients. J Clin Psychol Med Settings. 2010; 17(3):220-9. 